\title{
ANALISIS FAKTOR-FAKTOR PENGHAMBAT PRODUKTIVITAS PUBLIKASI KARYA ILMIAH MAHASISWA PPs UNY PADA JURNAL INTERNASIONAL TERINDEKS
}

\author{
Pardjono $^{1}$, Nuchron ${ }^{2}$, Surono $^{3}$, Sulaeman Deni Ramdani ${ }^{4}$ \\ ${ }^{1,2,3}$ Program Studi Pendidikan Teknik Mesin, Fakultas Teknik, Universitas Negeri Yogyakarta \\ ${ }^{4}$ Pendidikan Teknik Mesin, Universitas Sultan Ageng Tirtayasa \\ pardjono@uny.ac.id
}

\begin{abstract}
This research aims to reveal the inhibiting factors affecting the productivity of scientific papers publication of UNY graduate school students on indexed international journals, and students' expectation for the school administration to increase that productivity. This is a survey research carried out by the Graduate School of Universitas Negeri Yogyakarta (PPs UNY), involving 74 respondents. Data were obtained by means of questionnaire and were analyzed using descriptive statistical analysis. The results can be stated as follows. 1) The inhibiting factors came from external factors, namely busy workload, the high cost of international publishing, limited resource and access to printed journals subscription, and limited resource of online journals subscription. 2) Students' expectation to increase the productivity of indexed international journals publication are improvement in the dissemination of the program, access to information and services, English writing course, free translation, establish cooperation and networking, and subscription of online and printed journals.
\end{abstract}

Keywords: scientific paper, publication, indexed international journals

\begin{abstract}
ABSTRAK
Penelitian ini bertujuan untuk mengungkap: 1) faktor penghambat produktivitas mahasiswa dalam publikasi karya ilmiah pada jurnal internasional terindeks, 2) harapan mahasiswa kepada pengelola kampus untuk meningkatkan produktivitas publikasi karya ilmiah dalam jurnal internasional terindeks. Penelitian ini merupakan penelitian survei yang dilakukan di Program Pascasarjana Universitas Negeri Yogyakarta (PPs UNY) dengan responden berjumlah 74 orang. Teknik pengumpulan data menggunakan angket. Teknik analisis data menggunakan teknik analisis statistik deskriptif. Hasil penelitian dijelaskan sebagai berikut. 1) Faktor penghambat publikasi karya ilmiah pada jurnal internasional terindeks bersumber dari faktor eksternal yaitu kesibukan kerja, besarnya biaya, terbatasnya langganan jurnal cetak, terbatasnya langganan jurnal online, dan terbatasnya akses jurnal cetak. 2) Harapan Mahasiswa PPs UNY untuk meningkatkan produktivitas publikasi karya ilmiah dalam jurnal internasional terindeks yaitu perbaikan dan peningkatan dalam sosialisasi, akses informasi dan layanan, pelatihan penulisan dan bahasa Inggris, bantuan alih bahasa secara gratis, menjalin kerjasama dengan berbagai pihak, serta langganan jurnal online dan cetak.
\end{abstract}

Kata kunci: karya ilmiah, publikasi, jurnal internasional terindeks

\section{PENDAHULUAN}

Perguruan tinggi merupakan salah satu sumber potensial dalam menghasilkan penelitian dan pengembangan yang berkualtas, khususnya pada program pascasarjana. Penelitian merupakan salah satu kegiatan penting untuk mengembangkan ilmu pengetahuan dan memecahkan permasalahan. Inovasi dan pengembangan pendidikan dapat dilakukan melalui penelitian. Namun demikian, tidak cukup hanya berhenti sampai diperoleh hasil penelitian yang dimaksud. Hasil penelitian harus disebarluaskan untuk meningkatkan kebermanfaatannya melalui publikasi karya ilmiah. Publikasi karya ilmiah berfungsi sebagai dokumen atau catatan hasil penelitian yang dapat digunakan sebagai acuan oleh orang atau pihak lain yang membutuhkan informasi dan data akurat. Publikasi ilmiah merupakan karya aktualisasi diri dari penulis atau sebagai pengakuan untuk ide-ide dan 
hasil penelitian yang dilakukan. Selain itu, publikasi ilmiah dapat dijadikan trigger untuk menarik minat orang lain di daerah penelitian lainnya untuk memperkaya topik atau penelitian yang dikembangkan. Permendiknas No 17 tahun 2010 menyatakan bahwa karya ilmiah adalah hasil karya akademik mahasiswa/dosen/peneliti/tenaga kependidikan di lingkungan perguruan tinggi, yang dibuat dalam bentuk tertulis baik cetak maupun elektronik yang diterbitkan dan/atau dipresentasikan. Artinya, artikel mahasiswa menjadi sebuah karya ilmiah jika artikel itu telah dipublikasikan dalam jurnal atau dipresenstasikan dalam sebuah seminar.

Publikasi ilmiah dalam dunia pendidikan memiliki peranan yang sangat penting dalam pengembangan dan penyebarluasan informasi mengenai suatu topik. Sejak dikeluarkannya Surat Dirjen Dikti No. 1483/E/T/2012 mengenai penataan Program Doktor dan Surat Edaran Dikti No. 152/E/T/2012 mengenai Publikasi Ilmiah untuk $\mathrm{S} 1 / \mathrm{S} 2 / \mathrm{S} 3$, dosen dan mahasiswa lebih serius untuk melakukan publikasi karya tulis ilmiah. Dengan surat edaran tersebut diharapkan dapat menjadi solusi awal untuk mengatasi permasalahan lemahnya publikasi ilmiah yang dihasilkan oleh Indonesia. Jika edaran tersebut dapat dijalanka secara massif, diharapkan jumlah publikasi jurnal Indonesia dapat meningkat baik dari segi kuantitas maupun kualitasnya. Grafik dibawah ini adalah fakta mengenai capaian publikasi jurnal Indonesia dibandingkan dengan negara tetangga.

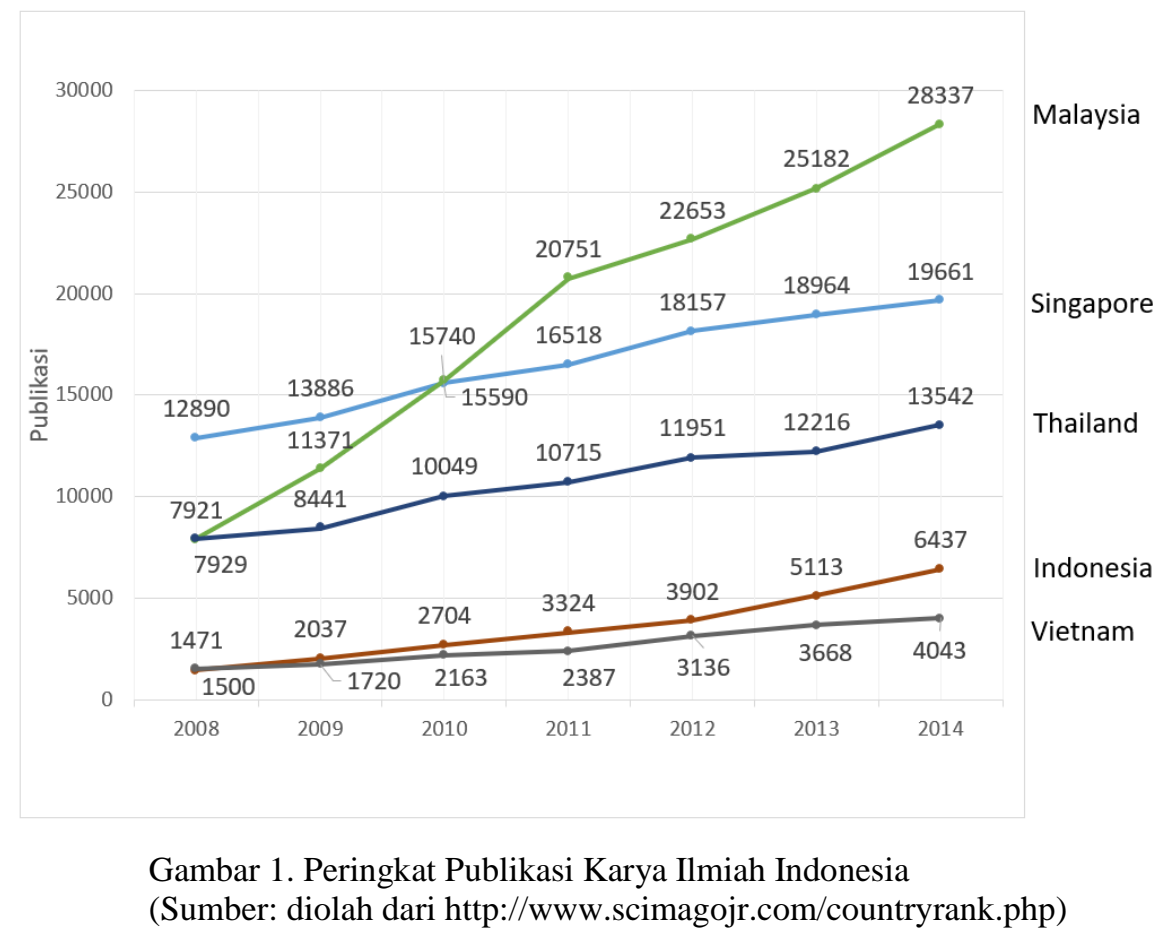

Gambar 1 menunjukkan bahwa jumlah publikasi ilmiah Indonesia sangat jauh dari peringkat atas terdekat yaitu Thailand pada tahun 2014. Jumlah publikasi Indonesia bahkan tidak mencapai $50 \%$ dari jumlah publikasi Thailand. Apalagi jika dibanding Singapore dan Malaysia. Lonjakan jumlah publikas yang sangat baik ditunjukkan oleh
Malaysia. Kita perlu belajar dari pengalaman Malaysia dalam mendongkrak publikasi ilmiah.

Perguruan tinggi khususnya jenjang pascasarjana memiliki peranan yang sangat penting dalam menghasilkan penelitian atau kajian ilmiah dalam dunia pendidikan. Hasilhasil penelitian mahasiswa pascasarjana yaitu 
tesis dan desertasi merupakan salah satu sumber publikasi karya ilmiah yang sangat potensial. PPs UNY dengan jumlah mahasiswa 1455 yang terdiri dari 2000 mahasiswa magister dan 309 mahasiswa doktoral (data tahun 2012), memiliki potensi untuk menghasilkan karya tulis ilmiah khususnya untuk dunia pendidikan yang sangat besar. Fakta menunjukan bahwa ranking UNY versi webometric menempati urutan ke 17 untuk tingkat Indonesia, peringkat 60 untuk tingkat Asia Tenggara, dan peringkat 2021 untuk tingkat dunia pada tahun
2015 dengan excellence rank 5414. Excellence merupakan jumlah artikel-artikel ilmiah publikasi perguruan tinggi yang bersangkutan yang terindeks di Scimago Institution Ranking (tahun 2003-2012) dan di Google Scholar (tahun 2007-2012). Meskipun UNY cenderung mengalami peningkatan dalam beberapa tahun terakhir, namun hal tersebut belum menunjukan angka yang signifikan sehingga perlu dilakukan usaha-usaha strategis untuk meningkatkan jumlah publikasi ilmiah baik skala nasional maupun internasional.

\begin{tabular}{|c|c|c|c|c|c|c|c|}
\hline ranking & $\begin{array}{l}\text { World } \\
\text { Rank }\end{array}$ & $\underline{\text { University }}$ & Det. & $\begin{array}{l}\text { Presence } \\
\underline{\text { Rank }}\end{array}$ & $\begin{array}{l}\underline{\text { Impact }} \\
\underline{\text { Rank }^{*}}\end{array}$ & $\begin{array}{l}\text { Openness } \\
\underline{\text { Rank }^{*}}\end{array}$ & $\begin{array}{l}\text { Excellence } \\
\text { Rank }\end{array}$ \\
\hline 9 & 1427 & $\begin{array}{l}\text { Universitas Pendikan Indonesia I } \\
\text { Indonesia University of Education }\end{array}$ & 필 & 677 & 709 & 152 & 5414 \\
\hline 10 & 1507 & Universitas Padjadjaran & $=$ & 1659 & 1511 & 263 & 3826 \\
\hline 11 & 1515 & Gunadarma University & w & 1395 & 1013 & 182 & 4808 \\
\hline 12 & 1579 & Institut Teknoloqi Sepuluh Nopember & 필 & 984 & 1943 & 658 & 3500 \\
\hline 13 & 1610 & $\underline{\text { Universitas Udayana }}$ & 필 & 1385 & 1633 & 278 & 4158 \\
\hline 14 & 1660 & $\underline{\text { Universitas Neqeri Semarang }}$ & 팔 & 1179 & 1203 & 91 & 5414 \\
\hline 15 & 1947 & $\underline{\text { Universitas Neqeri Malang }}$ & 필 & 784 & 2342 & 28 & 5414 \\
\hline 16 & 1988 & Hasanuddin University & 필 & 827 & 3438 & 301 & 3980 \\
\hline 17 & 2021 & Yogyakarta State University & 피 & 1251 & 1976 & 148 & 5414 \\
\hline 18 & 2060 & Petra Christian University & 라라 & 1080 & 3510 & 194 & 4158 \\
\hline 19 & 2128 & Universitas Riau & 팔 & 1312 & 3711 & 464 & 3826 \\
\hline
\end{tabular}

Gambar 2. Peringkat Webometrics UNY di tingkat Nasional dan Internasional pada Tahun 2015 (Sumber: http://www.webometrics.info/en/Asia/Indonesia)

PPs UNY memiliki potensi untuk menghasilkan karya tulis ilmiah yang berkualitas untuk dipublikasikan di tingkat nasional maupun internasional. Mahasiswa pascasarjana dengan pemikiran yang lebih dewasa dan produktif dalam menghasilkan penelitian untuk menemukan solusi atau memberikan invonasi baru dalam memperkaya khasanah ilmu pengetahuan merupakan salah satu modal untuk memperkuat publikasi ilmiah di UNY baik dari segi kuantitas maupun kualitasnya. Akses untuk mendapatkan informasi mengenai penelitian dan publikasi ilmiah cukup luas dan mudah karena mahasiswa mendapat fasilitas koneksi internet dengan bandwitch 670 Mbps pada tahun 2012 (http://puskom. uny.ac.id/en/akses-internet.html). Mahasiswa mendapatkan kuliah penulisan karya tulis ilmiah pada semester pendek untuk memperdalam kompetensi mengenai penulisan karya tulis ilmiah. Selain itu, ada pelatihan-pelatihan mengenai penulisan dan publikasi karya ilmiah untuk mahasiswa. Kemudahan-kemudahan tersebut ternyata tidak berbanding lurus dengan karya ilmiah (paper, artikel ilmiah, jurnal, prosiding, dll) yang dipublikasian baik secara regional, nasional, maupun internasional. Potensi yang tersedia belum dioptimalkan sepenuhnya untuk kepentingan publikasi karya ilmiah. Berdasarkan uraian di atas, penelitian ini bermaksud untuk mengungkap permasalahanpermasalahan mengenai produktifitas 
publikasi mahasiswa PPs UNY dan langkah strategis apa yang harus dilakukan untuk meningkatkan produktifitas publikasi karya ilmiah.

\section{METODE}

Penelitian ini merupakan penelitian survey. Penelitian ini dilakukan di PPs UNY dengan responden mahasiswa Strata 2 dan Strata 3 yang telah menyelesaikan pembuatan artikel jurnal ilmiah dan mengumpulkannya ke bagian jurnal PPs UNY. Penelitian ini dilaksanakan pada bulan Juni sampai dengan Oktober 2015 di PPs UNY. Populasi dalam penelitian ini adalah mahasiswa PPs UNY. Sampel diambil berdasarkan data mahasiswa yang telah mengumpulkan artikel jurnal ilmiah ke Bagian Jurnal PPs UNY pada bulan Juni sampai pertengahan Oktober 2015. Jumlah mahasiswa yang mengumpulkan jurnal berdasarkan data tersebut adalah 71 orang mahasiswa S2 dan 3 orang mahasiswa S3.

Teknik pengumpulan data dalam penelitian ini dilakukan dengan menggunakan angket. Angket disusun dengan menggunakan skala Likert 4 pilihan jawaban dilengkapi dengan pertanyaan terbuka. Analisis data dalam penelitian ini menggunakan teknik analisis statistik deskriptif. Teknik ini digunakan untuk mendeskripsikan faktorfaktor penghambat produktivitas publikasi karya tulis ilmiah. Skor penilaian dalam angket dikelompokan dalam empat kategori. Kategori data dimaksudkan untuk mengetahui pengelompokan data. Penentuan kategori secara teoritis berdasarkan kaidah distribusi normal sebagai mana disampaikan dalam Tabel 1.

Tabel 1. Pengkategorian Data

\begin{tabular}{lll}
\hline & Interval & \multicolumn{1}{c}{ Kategori } \\
\hline $\mathrm{Mi}+1,5 \mathrm{SD}$ & $<\mathrm{X} \leq \mathrm{Mi}+3 \mathrm{SD}$ & Sangat Baik/Sangat Tinggi \\
$\mathrm{Mi}$ & $<\mathrm{X} \leq \mathrm{Mi}+1,5 \mathrm{SD}$ Baik/Tinggi \\
$\mathrm{Mi}-1,5 \mathrm{SD}$ & $<\mathrm{X} \leq \mathrm{Mi}$ & Kurang/Rendah \\
$\mathrm{Mi}-$ 3SD & $\leq \mathrm{X} \leq \mathrm{Mi}-1,5 \mathrm{SD}$ & Sangat Kurang/Sangat \\
& & Rendah \\
\hline
\end{tabular}

Keterangan:

$$
\begin{aligned}
\mathrm{X}_{\mathrm{i}} / \mathrm{M}_{\mathrm{i}} & =\text { Rerata skor ideal } \\
& =1 / 2(\text { skor maksimal }+ \text { skor minimal) } \\
\mathrm{SBi} / \mathrm{SD} & =\text { Simpangan baku skor ideal } \\
& =1 / 6 \text { (skor maksimal }- \text { skor } \\
& \text { minimal) } \\
X & =\text { Skor aktual (skor yang dicapai) }
\end{aligned}
$$

Skor maksimal ideal $=\sum$ butir kriteria $x$ skor tertinggi

Skor minimal ideal $=\sum$ butir kriteria $x$ skor terendah

Analisis deskriptif juga digunakan untuk mengetahui pencapaian skor variabel dengan cara membandingkan skor total yang dicapai (empiris) dengan skor total tertinggi yang ditetapkan. Pencapaian skor tersebut dinyatakan dalam persentase yaitu persentase tertinggi $100 \%$ dan persentase terendah $25 \%$ (4 banding 1 sesuai skor dalam skala Likert) sehingga rerata ideal (Mi) sebesar $62,5 \%$ dan simpangan baku ideal (SDi) sebesar $12,5 \%$. Kriteria interpretasi datanya disampaikan dalam Tabel 2 berikut ini.

Tabel 2. Kriteria Interpretasi Data

\begin{tabular}{rlrl}
\hline \multicolumn{2}{c}{ Interval (\%) } & \multicolumn{1}{c}{ Kategori } \\
\hline 81 & $<\mathrm{X} \leq$ & 100 & Sangat Baik/Sangat Tinggi \\
63 & $<\mathrm{X} \leq$ & 81 & Baik/Tinggi \\
44 & $<\mathrm{X} \leq$ & 63 & Kurang/Rendah \\
25 & $\leq \mathrm{X} \leq$ & 44 & Sangat Kurang/Sangat \\
& & Rendah \\
\hline
\end{tabular}

Kriteria interpretasi data tersebut digunakan untuk menganalisis hasil penelitian dari instrumen angket yang digunakan.

\section{HASIL DAN PEMBAHASAN}

Faktor Penghambat Produktivitas

Mahasiswa PPs UNY dalam Publikasi

Karya Ilmiah pada Jurnal Internasional Terindeks

\section{Aspek Internal}

Aspek internal yang diamati terdiri atas dua indikator yaitu: 1) kompetensi, dan 2) motivasi. Kedua indikator tersebut dijabarkan dalam 7 butir pertanyaan untuk mengungkap seberapa baik kompetensi dan 
seberapa tinggi motivasi mahasiswa PPs UNY dalam membuat dan mempublikasikan karya tulis ilmiahnya pada jurnal internasional terindeks. Skor minimal per butir adalah 1 dan skor maksimal per butir adalah 4. Dengan demikian rentang skor yang ditetapkan pada aspek faktor internal ini adalah mulai 7 sampai dengan 28; rerata kriteria (Mi) sebesar 17,5; dan simpangan baku kriteria (SDi) sebesar 3,5.

Hasil analisis statistik deskriptif menunjukkan bahwa jawaban 74 responden memperoleh mean sebesar 19,06; median sebesar sebesar 19; dan mode sebesar 18. Data tersebut memiliki standar deviasi 3,24 dan varian 10,50. Nilai minimum yang diperoleh adalah 11 , nilai maksimumnya 26 , dan jumlah skor total (sum) adalah 1411. Berdasarkan data tersebut dapat ditentukan besarnya range $(\mathrm{R})=26-11=15$; jumlah kelas $(\mathrm{K})=1+3,3 \log 74=7,16$ dibulatkan menjadi 7; dan panjang interval $(\mathrm{P})=15: 7=2,14$ dibulatkan menjadi 2 . Penyebaran skor data variabel faktor penghambat produktivitas mahasiswa PPs UNY dalam publikasi karya ilmiah untuk jurnal internasional terindeks ditinjau dari aspek internal disampaikan dalam Tabel 3.

Tabel 3. Distribusi Frekuensi Data Variabel Faktor Penghambat Produktivitas Mahasiswa PPs UNY dalam Publikasi Karya Ilmiah untuk Jurnal Internasional Terindeks

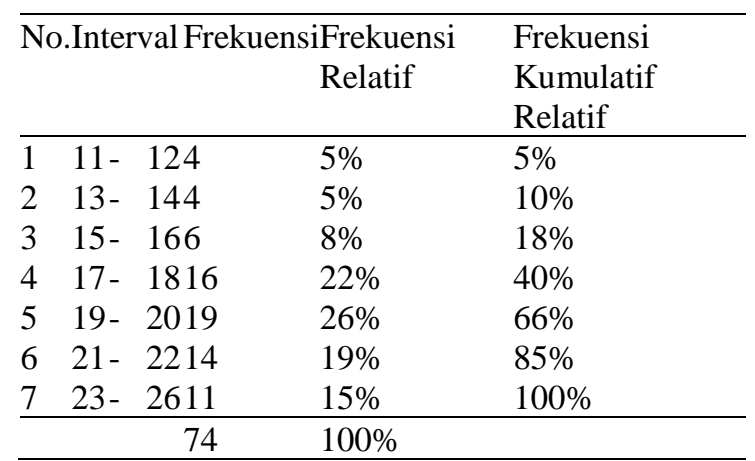

Berdasarkan hasil perhitungan
diperoleh rerata data hasil penelitian
(empiris) sebesar 19,06 . Nilai tersebut lebih
besar dibanding rerata kriteria sebesar 17,5 .
Hal tersebut menunjukkan bahwa faktor

internal yaitu kompetensi dan motivasi mahasiswa untuk mempublikasikan karya ilmiah dalam jurnal internasional terindeks termasuk kategori baik/tinggi. Selanjutnya, kecenderungan dari masing- masing skor dibedakan menjadi 4 kategori dengan rentang antara 7 sampai 28 yang secara rinci disajikan dalam Tabel 4.

Berdasarkan persentase kecenderungan data Tabel 4 tersebut dapat diketahui bahwa aspek internal yaitu kompetensi dan motivasi secara umum cenderung termasuk dalam kategori baik/tinggi sampai sangat baik/sangat tinggi. Hal ini selaras dengan rerata hasil penelitian yang telah dianalisis. Berdasarkan analisis deskriptif dapat pula diketahui pencapaian skor variabel dengan cara membandingkan skor total yang dicapai (empiris) dengan skor total tertinggi yang ditetapkan.

Tabel 4. Persentase Kecenderungan Skor Variabel Faktor Penghambat Produktivitas Mahasiswa PPs UNY dalam Publikasi Karya Ilmiah untuk Jurnal Internasional Terindeks Ditinjau dari Aspek Internal

\begin{tabular}{llll}
\hline Interval & Kategori & Frekuensi & Persentase \\
\hline $22,75<\mathrm{X} \leq 28$ & Sangat Baik/Sangat & 11 & $15 \%$ \\
& Tinggi & & \\
$17,5 \quad<\mathrm{X} \leq 22,75$ & Baik/Tinggi & 45 & $61 \%$ \\
$12,25<\mathrm{X} \leq 17,5$ & Kurang/Rendah & 14 & $19 \%$ \\
$7 \quad \leq \mathrm{X} \leq 12,25$ & Sangat Kurang/Sangat 4 & $5 \%$ \\
& Rendah & & \\
\hline Total & & 74 & $100 \%$ \\
\hline
\end{tabular}

Skor total yang diperoleh pada aspek internal adalah sebesar 1411 dan skor tertinggi yang ditetapkan sebesar 2072, sehingga persentase pencapaian skornya mencapai $68 \%$ dari skor tertinggi yang ditetapkan dengan kategori baik/tinggi. Dengan demikian, faktor internal berupa kompetensi dan motivasi tidak menjadi faktor penghambat produktivitas mahasiswa PPs UNY dalam publikasi jurnal internasional terindeks karena mahasiswa pascasarjana memiliki kompetensi yang baik dan motivasi yang tinggi untuk mempublikasikan karya tulis ilmiahnya dalam jurnal internasional terindeks dengan urutan sebagai berikut. 
Motivasi

1. Keinginan agar artikel ilmiahnya dikutip orang lain

2. Keinginan agar artikel ilmiahnya bisa dipublish

3. Keinginan menulis

Kompetensi

1. Kemampuan menuangkan ide/gagasan dalam tulisan ilmiah

2. Kemampuan identifikasi permasalahan/isu-isu strategis

3. Kemampuan/penguasaan bahasa baku

4. Pengetahuan tentang tata tulis dalam publikasi karya ilmiah

Hasil angket tersebut juga sesuai dengan penelusuran lebih lanjut kepada responden untuk mengetahui pengetahuan mereka mengenai struktur karya ilmiah. Mereka menyebutkan unsur-unsur pokok karya ilmiah yaitu judul, abstrak, pendahuluan, metode, hasil dan pembahasan, simpulan, dan referensi. Hal tersebut sesuai dengan pendapat Derntl (2014: 105) yang secara umum menyebutkan bahwa struktur karya ilmiah terdiri dari tiga bagian utama yaitu pendahuluan, isi, dan diskusi. Ada pula bagian lain yang tidak kalah penting yaitu judul, abstrak, dan referensi.

Secara lebih spesifik, Plaxco (2010: 2263) menyebutkan bahwa elemen yang harus ada dalam scientific paper setidaknya terdiri atas judul, abstrak, pendahuluan, metode, hasil, gambar dan judul halaman bab, dan sering kali terdapat bagian diskusi. Adanya perbedaan detail mengenai karya ilmiah tersebut merupakan hal wajar, sebagaimana disampaikan Dalman (2013: 11) yang secara tegas menjelaskan bahwa sistematika karya ilmiah bukanlah harga mati, karena sangat bergantung pada tradisi keilmuan dalam bidang tertentu dan jenis karya ilmiahnya. Berdasarkan hal tersebut, maka hal terpenting dalam menulis karya ilmiah adalah harus mengikuti sistematika yang diminta oleh media publikasi dan bergantung pada jenis karya ilmiahnya.

\section{Aspek Eksternal}

Aspek eksternal yang diamati terdiri atas lima indikator yaitu: 1) keluarga, 2) kesibukan di luar kuliah, 3) lingkungan akademik, 4) regulasi kampus, 5) fasilitas kampus. Indikator-indikator tersebut dijabarkan dalam dalam 16 butir pertanyaan. Skor minimal per butir adalah 1 dan skor maksimal per butir adalah 4, sehingga rentang skor yang ditetapkan pada aspek faktor eksternal ini adalah mulai 16 sampai dengan 64; rerata kriteria (Mi) sebesar 40 dan simpangan baku kriteria (SDi) sebesar 8 .

Hasil analisis statistik deskriptif menunjukkan bahwa jawaban 74 responden memperoleh mean sebesar 45,62; median sebesar 50; dan mode sebesar 49. Data tersebut memiliki standar deviasi 6,73 dan varian 45,36 . Nilai minimum yang diperoleh adalah 23, nilai maksimumnya 59, dan jumlah skor total (sum) adalah 3376. Berdasarkan data tersebut dapat ditentukan besarnya range $(R)=59-23=36$; jumlah kelas $(\mathrm{K})=1+3,3 \log 74=7,16$ dibulatkan menjadi 7; dan panjang interval $(\mathrm{P})=36: 7$ $=5,14$ dibulatkan menjadi 5. Penyebaran skor data variabel faktor penghambat produktivitas mahasiswa PPs UNY dalam publikasi karya ilmiah untuk jurnal internasional terindeks ditinjau dari aspek eksternal disampaikan dalam Tabel 5.

Tabel 5. Distribusi Frekuensi Data Variabel Faktor Penghambat Produktivitas Mahasiswa PPs UNY dalam Publikasi Karya Ilmiah untuk Jurnal Internasional Terindeks Ditinjau dari Aspek Eksternal

\begin{tabular}{lllll}
\hline No. Interval & $\begin{array}{c}\text { Frekuensi Frekuensi } \\
\text { Relatif }\end{array}$ & $\begin{array}{l}\text { Frekuensi } \\
\text { Kumulatif } \\
\text { Relatif }\end{array}$ \\
\hline 1 & $23-27$ & 1 & $1 \%$ & $1 \%$ \\
2 & $28-32$ & 2 & $3 \%$ & $4 \%$ \\
3 & $33-37$ & 6 & $8 \%$ & $12 \%$ \\
4 & $38-42$ & 10 & $14 \%$ & $26 \%$ \\
5 & $43-47$ & 24 & $32 \%$ & $58 \%$ \\
6 & $48-52$ & 20 & $27 \%$ & $85 \%$ \\
7 & $53-59$ & 11 & $15 \%$ & $100 \%$ \\
\hline \multicolumn{5}{c}{74} \\
\hline
\end{tabular}


Kecenderungan data variabel faktor penghambat produktivitas mahasiswa PPs UNY dalam publikasi karya ilmiah untuk jurnal internasional terindeks ditinjau dari aspek eksternal dapat diketahui dengan membandingkan besarnya rerata hasil penelitian (empiris) dengan rerata kriteria yang ditetapkan. Berdasarkan hasil perhitungan diperoleh rerata data hasil penelitian (empiris) sebesar 45,62. Nilai tersebut lebih besar dibanding rerata kriteria sebesar 40. Hal tersebut menunjukkan bahwa faktor eksternal yaitu keluarga, kesibukan di luar kuliah, lingkungan akademik, regulasi kampus, dan fasilitas kampus termasuk kategori tinggi dalam mempengaruhi produktivitas mahasiswa PPs UNY dalam publikasi karya ilmiah untuk jurnal internasional terindeks. Selanjutnya, kecenderungan dari masing-masing skor dibedakan menjadi 4 kategori dengan rentang antara 16 sampai 64 yang secara rinci disajikan dalam Tabel 6.

Tabel 6. Persentase Kecenderungan Skor Variabel Faktor Penghambat Produktivitas Mahasiswa PPs UNY dalam Publikasi Karya Ilmiah untuk Jurnal Internasional Terindeks Ditinjau dari Aspek Eksternal

\begin{tabular}{|c|c|c|c|}
\hline Interval & Kategori & Frekuensi & Persentase \\
\hline \multicolumn{2}{|c|}{$52<X \leq 64$ Sangat Tinggi } & 11 & $15 \%$ \\
\hline \multicolumn{2}{|c|}{$40<X \leq 52$ Tinggi } & 48 & $65 \%$ \\
\hline \multicolumn{2}{|c|}{$28<X \leq 40$ Rendah } & 14 & $19 \%$ \\
\hline \multicolumn{2}{|c|}{$16 \leq X \leq 28$ Sangat Rendah } & 1 & $1 \%$ \\
\hline \multicolumn{2}{|l|}{ Total } & 74 & $100 \%$ \\
\hline
\end{tabular}

Berdasarkan persentase kecenderungan data tersebut dapat diketahui bahwa aspek eksternal yaitu keluarga, kesibukan di luar kuliah, lingkungan akademik, regulasi kampus, dan fasilitas kampus secara umum cenderung termasuk dalam kategori tinggi sampai sangat tinggi. Hal ini selaras dengan rerata hasil penelitian yang telah dianalisis. Berdasarkan analisis deskriptif dapat pula diketahui pencapaian skor variabel dengan cara membandingkan skor total yang dicapai (empiris) dengan skor total tertinggi yang ditetapkan.
Variabel faktor penghambat produktivitas mahasiswa PPs UNY dalam publikasi karya ilmiah untuk jurnal internasional terindeks ditinjau dari aspek eksternal memperoleh skor total 3376 dan skor tertinggi yang ditetapkan adalah 4736 . Jika dihitung persentase pencapaian skornya, maka skor variabel tersebut mencapai $71 \%$ dari skor tertinggi yang ditetapkan dengan kategori tinggi. Dengan demikian, faktor eksternal berupa keluarga, kesibukan di luar kuliah, lingkungan akademik, regulasi kampus, dan fasilitas kampus menjadi faktor penghambat produktivitas mahasiswa PPs UNY dalam publikasi karya ilmiah untuk jurnal internasional terindeks. Lima urutan teratas faktor yang menghambat produktifitasnya adalah sebagai berikut.

1. Kesibukan kerja.

2. Besarnya biaya.

3. Ketersediaan langganan jurnal cetak.

4. Kersediaan langganan jurnal online.

5. Akses jurnal cetak.

Hasil penelitian tersebut ternyata
memiliki perbedaan dari beberapa permasalahan yang disampaikan oleh Cargill \& O'Connor (2009: 5) yang menyatakan beberapa alasan kenapa peneliti mengalami kesulitan dalam publikasi ilmiah yaitu: (1) Not all research is new or of sufficient scientific interest. (2) Experiments do not always work: positive result are easier to publish. (3) Scientific journals have specific requirements which can be difficult to meet: publishing is a buyer's market. Dengan kata lain, tidak semua hasil penelitian merupakan kategori penelitian baru atau up to date. Beberapa hasil penelitian eksperimen tidak selalu menghasilkan kesimpulan yang diharapkan, hasil yang positif lebih mudah untuk dipublikasikan. Selain itu beberapa jurnal memiliki syarat yang sulit untuk dipenuhi oleh peneliti. Perbedaan tersebut dapat terjadi karena sudut pandang yang digunakan.

Sudut pandang berbeda juga disampaikan oleh Kaswan Darmadi (1996) 
yang berpendapat bahwa menulis merupakan kemampuan yang paling sulit dibandingkan dengan menyimak, berbicara, ataupun membaca. Kemampuan menulis menjadi permasalahan yang dihadapi oleh setiap orang. Kemudian, secara lebih rinci, Herry Kamaroesid (2009: 5) menyebutkan bahwa kendala terbesar dalam menulis karya ilmiah berasal dari dalam diri sendiri, khususnya adanya pandangan diri bahwa menulis perlu bakat, kemampuan menulis itu faktor keturunan, dan membutuhkan tenaga ekstra. Pandangan-pandangan tersebut yang sering menjadi kendala penulisan karya ilmiah.

Selain permasalahan yang sudah disampaikan sebelumnya, permasalahan lain yang dihadapi mahasiswa S2 dan S3 dalam publikasi jurnal internasional sebagai berikut.

1. Masih kurangnya reviewer dari universitas yang ditugaskan untuk meninjau karya atau penelitian yang akan diterbitkan untuk jurnal internasional.

2. Belum ada perencanaan secara terstruktur yang mengarahkan peneliti untuk mempublikasikan penelitian secara internasional.

Harapan Mahasiswa PPs UNY Kepada Pengelola dalam Rangka Meningkatkan Produktivitas Publikasi Karya Ilmiah dalam Jurnal Internasional Terindeks

1. Adanya sosialisasi cara pengiriman karya ilmiah.

2. Adanya peningkatan akses informasi dan layanan untuk penulisan jurnal internasional.

3. Memberikan pelatihan karya ilmiah jurnal internasional secara intensif.

4. Ada bantuan alih bahasa secara gratis.

5. Pihak universitas menjalin kerjasama dengan beberapa pihak terkait untuk mempermudah penerbitan jurnal.

6. Ketersediaan langganan jurnal online dan cetak ditingkatkan.

7. Memberikan pelathian bahasa asing, khususnya bahasa Inggris secara intensif.

\section{SIMPULAN}

1. Faktor penghambat produktivitas mahasiswa PPs UNY dalam publikasi karya ilmiah pada jurnal internasional terindeks bersumber dari faktor eksternal (di luar diri mahasiswa) yaitu kesibukan kerja, besarnya biaya, ketersediaan langganan jurnal cetak, ketersediaan langganan jurnal online, dan akses jurnal cetak.

2. Harapan Mahasiswa PPs UNY kepada pengelola PPs UNY dalam rangka meningkatkan produktivitas publikasi karya ilmiah dalam jurnal internasional terindeks yaitu adanya sosialisasi cara pengiriman karya ilmiah, adanya peningkatan akses informasi dan layanan untuk penulisan jurnal internasional, memberikan pelatihan karya ilmiah jurnal internasional secara intensif, ada bantuan alih bahasa secara gratis, pihak universitas menjalin kerjasama dengan beberapa pihak terkait untuk mempermudah penerbitan jurnal, ketersediaan langganan jurnal online dan cetak ditingkatkan, memberikan pelatihan bahasa Inggris secara intensif.

\section{DAFTAR RUJUKAN}

Cargill, M., \& O’Connor, P. (2009). Writing scientific research articles. South Australia: Willey Blackwell.

Dalman. (2013). Menulis karya ilmiah. Jakarta: Raja Grafindo Persada.

Derntl, M. (2014). Basics of research paper writing and publishing. Int. $J$. Technology Enhanced Learning, Vol. 6, No. 2, pp.105-123.

Herry Kamaroesid. (2009). Menulis karya ilmiah untuk jabatan guru. Jakarta: Gaung Persada.

Kaswan Darmadi. (1996). Meningkatkan kemampuan menulis: panduan untuk mahasiswa dan calon mahasiswa. Yogyakarta: Andi Offset. 
Plaxco, K.W. (2010). The art of writing science. Protein Science, Vol. 19, pp.2261-2266.

Presiden. (2010). Peraturan Menteri Pendidikan Nasional Nomor 17 Tahun
2010, tentang Pencegahan dan Penanggulangan Plagiat di Perguruan Tinggi. 